\title{
Pendidikan politik perempuan dalam menghadapi pemilihan kepala daerah Provinsi Jambi tahun 2020
}

\author{
Sutri Destemi*, \& Hartati \\ Program Studi Ilmu Politik, Universitas Jambi \\ * elsisutri@gmail.com
}

\begin{abstract}
Abstrak. Berbagai terobosan melalui kebijakan afirmasi dan penguatan peran perempuan dalam politik terus diupayakan. Salah satu upaya tersebut dapat dilihat melalui penerapan Undang-undang Pemilu yang mensyaratkan keterlibatan perempuan minimal 30 persen sebagai calon anggota legislatif yang diusung parpol. Kebijakan tersebut secara tegas juga diterjemahkan oleh Komisi Pemilihan Umum (KPU) dalam peraturan KPU Nomor 7/2013 yang menyebutkan bahwa parpol yang tidak dapat memenuhi syarat tersebut tidak dapat lolos sebagai peserta pemilu. Akan tetapi pada tahap pelaksanaannya tingkat partisipasi perempuan dalam politik masih rendah. Parpol belum mampu menghasilkan kader perempuan yang handal. Asumsi dasar yang melatarbelakangi hal ini adalah pendidikan politik terhadap perempuan di Indonesia yang belum cukup untuk membuka kesadaran politik. Metode yang digunakan dalam pengabdian ini adalah pemberdayaan masyarakat melalui pendidikan politik terhadap kelompok/organisasi/komunitas perempuan yang tedapat di Kelurahan Pijoan. Fungsi pendidikan politik tidak hanya menjadi peran Parpol akan tetapi juga beralih pada semua lapisan masyarakat, terutama lingkungan pendidikan dan para akademisi. Oleh karena itu pengabdian ini diharapkan mampu meningkatkan kesadaran masyarakat khususnya perempuan untuk berpartisipasi aktif dalam pemilihan kepala daerah provinsi Jambi mendatang. Berdasarkan hasil survey yang dilaksanakan setelah pengabdian, para peserta memperoleh motivasi untuk lebih aktif dalam berbagai kegiatan seperti organisasi maupun dalam aktifitas pemerintahan dan politik.
\end{abstract}

Kata kunci: pendidikan politik, perempuan, pijoan.

\begin{abstract}
Abstrak. We continue to pursue various breakthroughs through affirmative policies and strengthening the role of women in politics. One of these efforts can be seen through the application of the Election Law which requires the involvement of women at least 30 percent as legislative candidates for political parties. This policy is explicitly translated by the General Election Commission (KPU) in KPU regulation Number 7/2013 which states that political parties that cannot meet these requirements cannot qualify as election participants. However, at the implementation stage the level of women's participation in politics is still low. Political parties have not been able to produce reliable female cadres. The basic assumption behind this is that political education for women in Indonesia is not sufficient to open political awareness. The method used in this service is community empowerment through political education for women's groups / organizations / communities in Pijoan Village. The function of political education is not only the role of Political Parties but also transfers to all levels of society, especially the educational environment and academics. Therefore, this service is expected to be able to increase public awareness, especially women, to actively participate in the upcoming regional head elections for Jambi province. Based on the results of the survey carried out after the service, the participants received motivation to be more active in various activities such as organizations and in government and political activities.
\end{abstract}

Keyword: political education, women, pijoan.

To cite this article: Destemi, S., \& Hartati. 2020. Pendidikan politik perempuan dalam menghadapi pemilihan kepala daerah Provinsi Jambi tahun 2020. Unri Conference Series: Community Engagement 2: 265-268. https://doi.org/10.31258/unricsce.2.265-268

\section{(C) 2020 Authors}

Peer-review under responsibility of the organizing committee of Seminar Nasional Pemberdayaan Masyarakat 2020 


\section{PENDAHULUAN}

Dewasa ini kebijakan afirmatif telah dicetuskan untuk mendorong kaum wanita aktif dalam tataran publik, meskipun demikian perdebatan tentang posisi tersebut masih terus berhadapan dengan nilai budaya, agama dan lingkungan sosial bahkan lingkunga keluarga. Perdebatan tentang kiprah perempuan dalam politik pada tingkat lokal / grassroot pada akhirnya harus mengalah terhadap nilai budaya dan adat istiadat. Kehadiran perempuan sebagai kelas kedua terus dijadikan alasan bahwa laki-laki berhak sebagai kelompok pengambil kebijakan. Dampaknya kemudian meluas pada tahapan pengambilan keputusan, semakin sedikit jumlah perempuan yang aktif dalam tahap formulasi kebijakan sehingga kepentingan perempuan menjadi termarginalkan.

Jika melihat perkembangan dunia politik saat ini jumlah keterwakilan perempuan masih sangatlah sedikit. Kekangan lingkungan sosial berpengaruh terhadap motivasi wanita untuk mempelajari dan memahami makna politik sebenarnya. Perjalanan wanita dalam kerangka nilai sosial budaya telah membentuk wanita yang apatis terhadap politik, sehingga tidak mengherankan apabila partisipasi wanita dalam politik juga rendah. Wanita tidak memahami arti penting kehadiran wanita dalam pengambilan keputusan, sehingga kedudukan wanita diposisikan seperti supporter bagi pria (Hannam,2007:8).

Sejalan dengan upaya peningkatan partisipasi perempuan dalam politik, maka hal yang paling mendasar untuk dilakukan adalah dengan meningkatkan kesadaran wanita melalui pendidikan politik. Melalui pendidikan politik, diharapkan dapat membuka wawasan wanita dan memberi motivasi wanita untuk dapat berpartisipasi, minimal dalam tatanan politik aras lokal ditingkat terendah, seperti lingkungan keluarga, lingkungan tempat tinggal atau aktifitas politik di tingkat desa. Wanita masa kini harus cerdas dalam memanfaatkan peluang dan mengatasi tantangan untuk memperjuangkan haknya.

Oleh sebab itu berbagai tantangan dan hambatan yang dilalui oleh wanita juga harus diketahui dan dipahami baik oleh laki-laki maupun perempuan itu sendiri. Dalam tatanan politik di aras lokal berbagai organisasi yang mewadahi perempuan sangat penting memperoleh pendidikan politik, seperti PKK, kelompok arisan dan yasinan/ majelis taklim, komunitas komunitas yang bergerak di bidang pemberdayaan perempuan, namun demikian juga tetap melibatkan organisasi dan kelompok yang mayoritas beranggotakan laki-laki. Organisasi tersebut dapat menjadi wadah bagi perempuan untuk dapat berkumpul memperoleh pengetahuan, serta dapat menyampaikan gagasannya sehingga dapat aktif dalam aktifitas publik.

Keberadaan organisasi perempuan seperti PKK, Dharmawanita, Karang Taruna dan kelompok lainnya masih sangat terbatas pada aktifitas domestik saja, belum mengarah kepada pada posisi perempuan sebagai counter dalam kehidupan bermasyarakat. Selain itu seringkali keberadaan organisasi itu sering kali hanya sebagai pelengkap dari keberagaman organisasi. Sejalan dengan kondisi tersebut, menarik pula untuk menilik salah satu contoh kasus yang menggambarkan bahwa kurangnya pendidikan politik yang diperoleh oleh wanita sehingga berdampak pada kurangnya tingkat partisipasi perempuan dalam bidang politik. Sebagai salah satu contohnya penulis mengambil lokasi di salah satu kecamatan di Kabupaten Muaro Jambi. Alasan pemilihan lokasi adalah Kecamatan dengan jumlah Desa/Kelurahan yang terbanyak yaitu sebanyak 20 Desa, yaitu Kecamatan Jambi Luar Kota. Kemudian untuk memperoleh informasi yang lebih mendalam, maka dipilih salah satu kelurahan yang dianggap cukup representatif terhadap jumlah organisasi perempuan serta organisasi lainnya.

Kesadaran dan "melek" politik perempuan masih rendah, begitu juga dengan penerimaan laki-laki terhadap perempuan yang berkiprah dalam politik juga masih terbatas. Persoalan yang serupa juga terjadi pada Kecamatan Jambi Luar Kota dan Keluraha Pijoan khususnya. Perempuan masih sangat terikat dengan nilai sosial budaya di masyarakat yang masih asing dengan politik dan cenderung tertutup. Jika ditinjau dari wilayah geografis, kelurahan Pijoan memiliki lokasi strategis karena berdekatan dengan pusat pendidikan Provinsi Jambi yaitu Universitas Jambi dan Universitas Islam Negeri Sultan Thaha, Universitas Batanghari, serta beberapa Universitas dan lembaga pendidikan lainnya, namun demikian hal tersebut tidak menunjukkan pesatnya pengetahuan politiknya.

Berdasarkan analisis situasi, terdapat beberapa persoalan yang mendasar, yaitu:

1. Bagaimana pengetahuan masyarakat khususnya perempuan tentang politik di Kelurahan Pijoan Kecamatan Jambi Luar Kota

2. Mengapa partisipasi politik perempuan di Kelurahan Pijoan Kecamatan Jambi Luar Kota rendah 


\section{METODE PENERAPAN}

Metode pelaksanaan yang dilakukan dalam memberikan pendidikan politik perempuan dilakukan dengan metode ceramah dan diskusi yang melibatkan organisasi perempuan PKK, Dharmawanita, karang taruna, Ibu rumah tangga serta masyarakat desa pada umumnya untuk dapat menggali lebih jauh mengenai pokok-pokok pikiran, informasi dan solusi yang dapat diberikan dalam memotivasi masyarakat khususnya perempuan untuk berpartisipasi aktif dalam mensukseskan penyelenggaraan pemilihan kepala daerah di Provinsi Jambi Tahun 2002. Pelaksanaan pengabdian ini melibatkan beberapa pihak yaitu Kelurahan Pijoan dan Kecamatan Jambi Luar Kota sebagai mitra kerjasama, selain itu juga melibatkan Komisi Pemilihan Umum Muaro Jambi dan Komisi Pemilihan Umum Kota Jambi.

Beberapa program kegiatan pengabdian yang dilakukan berupa:

a. Pelatihan untuk memberi pemahaman pentingnya partisipasi perempuan dalam pembangunan, penggunaan hak pilih dalam pemilihan umum

b. Sosialisasi tentang kebijakan responsif gender (Undang-undang Partai Politik dan Undang-undang Pemilihan Umum No.7 Tahun 2017)

\section{HASIL DAN KETERCAPAIAN}

\section{a. Tingkat pengetahuan perempuan tentang hak politiknya}

Berbagai informasi yang disampaikan peserta cukup bervariatif. Ada yang mengemukakan bahwa memang pemimpin itu memang harus laki-laki dengan dasar aturan agama bahwa seorang pemimpin adalah laki-laki. Selanjutnya adanya pemahaman bahwa ketika perempuan terlalu banyak beraktivitas di lingkungan publik seperti organisasi maka urusan domestik tidak tercapai. Pendapat yang ketiga menyatakan bahwa jika terlalu sibuk untuk urusan publik maka aktivitas domestik memerlukan bantuan pihak ketiga yang berdampak pada pengeluaran ekonomi semakin besar serta belum tentu pola pengasuhan anak terjamin. Sehingga muncul ketakutan dan kekhawatiran ketika ada campur tangan pihak ke tiga di dalam rumah tangga. Informasi berikutnya adalah kenyataan bahwa sebenarnya dari perempuan yang ada di kelurahan Pijoan yang masih memiliki pola pikir dan pemahaman masing-masing sehingga enggan jika banyak beraktivitas di ruang publik. Maksudnya adalah adanya keengganan untuk menjadi sosok yang diprioritaskan di masyarakat dan cenderung menyerahkan kepada laki-laki. Sehingga meskipun ada kesempatan maka yang banyak mengisi kesempatan tersebut adalah laki-laki.

\section{b. Faktor-Faktor Yang Mempengaruhi Partisipasi Politik Perempuan Di Kelurahan Pijoan}

Melihat kondisi yang terjadi di lapangan dapat diperoleh informasi bahwa masih minimnya partisipasi politik perempuan di Keluarahan Pijoan karena berbagai faktor secara umum yakni :

1. Adanya sistem kebijakan dan peraturan masyarakat yang lebih banyak memberikan akses bagi laki-laki. Terlihat pada rumusan bahwa bukan masalah laki-laki dan perempuan, tetapi pada masalah kriteria yang harus dipenuhi. Memang sudah ada kriteria sejak awal bahwa laki-laki yang diprioritaskan.

2. Adanya keterbatasan perempuan yang menyangkut kapasitas SDM. Hal ini nampak pada rumusan perempuan tidak bisa dipaksakan untuk memberi sambutan, memberikan pengarahan dan lain-lain. Padahal sudah banyak kesempatan yang telah diberikan pada perempuan. Artinya bahwa dalam situasi tertentu perempuan sebenarnya memiliki kesempatan namun masih ada rasa kurang percaya diri pada beberapa perempuan untuk dapat tampil atau memimpin di depan umum. Ada tekanan sosial tertentu yang dirasakan perempuan.

3. Role models menjadi sangat diperlukan di dalam perkembangan sebuah masyarakat. Hal ini nampak pada rumusan menjadi permasalahan sebenarnya bukan kesempatan bagi perempuan yang kurang tetapi lebih pada perempuannya sendiri yang belum siap. Karena kebanyakan perempuan sendiri yang masih belum siap, belum pede dan sebagainya. Sehingga memerlukan role models yang membuat perempuan-perempuan lain termotivasi.

\section{c. Pelaksanaan Pendidikan Politik Perempuan di Kelurahan Pijoan}

Kegiatan ini dilaksanakan dengan mekanisme kegiatan sosialisasi terbagi menjadi 3 sesi yakni Sosialisasi I (brainstorming), Sosialisasi II (Pemaparan Materi) dan Sosialisasi III (Analisis Permasalahan Lapangan).Melalui Sosialisasi tim pengabdian menyampaikan tentang seks dan gender, ideologi patriarkhi dan politik perempuan. 
Dalam kajian seks dan gender membahas terkait dengan perbedaan antara perspektif seks dan gender, mengkaji definisi kultur dan biologi pada laki-laki dan perempuan serta bentuk-bentuk ketidakadilan gender. Selanjutnya membahas mengenai ideologi patriarkhi dan pada akhir materi terkait dengan politik perempuan. Politik perempuan membahas mengenai partisipasi politik perempuan. Pada tahap berikutnya fasilitator juga menegaskan bahwa akses dan kontrol perempuan terhadap pengambilan keputusan mencakup beberapa aspek yaitu :

1. Akses, yaitu pengakuan, peluang, dan jaminan kebebasan bagi perempuan untuk menentukan pilihan

2. Penyadaran, yaitu proses penyadaran dan pengenalan identitas pribadi perempuan di tengah-tengah kehidupan sosial dan politik

3. Partisipasi, yaitu keterlibatan perempuan secara penuh dalam semua tingkatan pengambilan keputusan

4. Kontrol, yaitu kewenangan atau hak yang sama setiap perempuan untuk menggunakan dan mengawasi pelaksanaan setiap keputusan

5. Kesejahteraan, yaitu hak yang sama bagi setiap perempuan untuk mendapatkan manfaat dari setiap keputusan serta hak untuk menggunakan sumber-sumber kehidupan atau faktor-faktor produksi seperti modal, sumber daya alam, dan tenaga kerja. Fasilitator menambahkan bahwa perempuan harus ikut serta dalam proses pembuatan kebijakan publik karena perempuan memiliki kebutuhan-kebutuhan khusus yang hanya dapat dipahami paling baik oleh perempuan sendiri. Kebutuhan-kebutuhan ini meliputi: isu-isu kesehatan reproduksi, seperti cara KB yang aman; isu-isu kesejahteraan keluarga, seperti harga sembilan bahan pokok yang terjangkau; masalah kesehatan dan pendidikan anak; isu-isu kepedulian terhadap anak, kelompok usia lanjut dan tuna daksa; serta isu-isu kekerasan seksual.

\section{KESIMPULAN}

Partisipasi perempuan yang belum maksimal dibandingkan dengan partisipasi laki-laki di lingkungan organisasi, kegiatan masyarakat dan tatanan struktural pemerintahan desa adalah salah satu fenomena di Keluarahan Pijon Kecamatan Jambi Luar Kota Kabupaten Muaro Jambi. Faktor minimnya partisipasi perempuan di bidang politik dapat dibedakan menjadi faktor eksternal dan internal. Faktor eksternal meliputi adanya manipulasi budaya dan agama dalam kepentingan partisipasi politik perempuan, keterbatasan akses terkait sistem social masyarakat, dan penerimaan kultural dari masyarakat. Faktor Internal meliputi keberadaan perempuan yang kurang memaksimalkan potensi yang ada dalam dirinya , perempuan sering kurang percaya diri, kesadaran diri tentang hak dan kewajiban perempuan di dalam keluarga dan lingkungan yang masih terbatas. Sebagai penutup dari rangkaian kegiatan ini tim pengabdian mengucapkan terimakasih dan apresiasi kepada Universitas Jambi melalui Fakultas Ilmu Sosial dan Ilmu Politik sebagai penyandang dana atas kegiatan ini.

\section{DAFTAR PUSTAKA}

Hannam, June. 2007. Feminism. Eangland. Pearson Education.

Illich Ivan. 2007. Matinya Gender. Yogyakarta. Pustaka Pelajar.

Mulia, Siti Musdah dan Anik Farida. 2005. Perempuan dan Politik. Jakarta. PT SUN.

Nugroho Riant.2008. Gender dan Strategi Pengarus-utamaannya di Indonesia.Yogyakarta. Pustaka Pelajar.

Saadawi Nawal El.2011. Perempuan Dalam Budaya Partriarki.Yogyakarta. Pustaka Pelajar.

Saptari Ratna dan Brigitte M. Holzner. 1997. Perempuan, kerja, dan Perubahan Sosial. Jakarta. Pustaka Utama Grafiti.

Tong, Rosemary Putnam. 2010. Feminist Thought: Pengantar paling Komprehensif Kepada Aliran Utama Pemikiran Feminis. Yogyakarta: Jalasutra. 